\title{
On the Epistemic Role of Our Passional Nature
}

\author{
FREDERICK D. AQUINO AND LOGAN PAUL GAGE*
}

"Love is itself a form of knowledge."

- Gregory the Great -

CAN OUR PASSIONAL NATURE play a legitimate epistemic role in our lives? In this Aarticle, we argue that John Henry Newman was right to think that our passional nature can indeed play such a role. First, we unpack the standard objection to Newman's understanding of the relationship between our passional nature and the evidential basis of faith. We use "passional nature" as an umbrella term to cover the affective side of the person (passions, affections, emotions) that often bears on the pursuit of epistemic goods like true belief, knowledge, and wisdom. Second, we argue that the standard objection to Newman operates with a narrow definition of evidence (where evidence is synonymous with arguments and a third-person perspective). After challenging this notion, we then offer a broader and more humane understanding of evidence. Third, we survey recent scholarship arguing that emotions, a key aspect of our passional nature, are cognitive. In this light, they plausibly have a proper epistemic role. Fourth, we defend Newman's reliance on the passional nature in epistemic matters by showing how reasonable it is in light of this recent work on evidence and the nature of emotions. Newman's insistence that the formation of a right state of heart and mind is crucial for epistemic success is far from untenable.

\section{THE STANDARD OBJECTION}

Newman claims that seemingly non-epistemic factors such as desire, hope, fear, and love play an important role in forming and sustaining Christian belief.

\footnotetext{
Frederick D. Aquino is Professor of Theology and Philosophy at the Graduate School of Theology, Abilene Christian University (ACU), and the director of the philosophy minor at ACU. His publications are in the areas of religious epistemology, spiritual perception, John Henry Newman, and Maximus the Confessor. Logan P. Gage is Associate Professor of Philosophy at Franciscan University of Steubenville. He works primarily in epistemology and natural theology. 1 "Amor ipse notitia est." Gregory the Great, Homily 27.4 on the Gospel of John, cited and trans. Robert Louis Wilken, The Spirit of Early Christian Thought: Seeking the Face of God (New Haven: Yale University Press, 2003), 312.
} 
For example, he says that the "desire" of faith "is its main evidence."2 "Faith is influenced by previous notices, prepossessions, and (in a good sense of the word) prejudices. . . The mind that believes is acted upon by its own hopes, fears, and existing opinions." ${ }^{3}$ While he clearly thinks that faith is rational or an "act of Reason," it is a reasoning "upon holy, devout, and enlightened presumptions." ${ }^{4}$ In other words, a properly disposed mind or a "right state of heart" creates and disciplines faith, while guarding it from deficiencies such as superstition, fanaticism, and dogmatism. ${ }^{5}$ Love, Newman boldly insists, is the very safeguard of rational faith.

An immediate challenge, however, involves clarifying how these seemingly non-epistemic factors play an epistemic role in the formation and sustenance of Christian faith. In fact, a standard criticism is that Newman's emphasis on these non-epistemic factors falls prey to a kind of subjectivism, fideism, or relativism. ${ }^{6}$ The charge here has been framed primarily as a problem of adjudication. For example, Jay Newman argues that John Henry Newman's emphasis on love as a safeguard of faith fails to solve the problem of adjudicating Christian beliefs in a publicly accessible manner. John Henry Newman's claim that love serves as the safeguard of faith exacerbates the problem by giving others the same kind of justification for their own perspective. Although it is somewhat expected that a Christian philosopher would "assign to love a conspicuous place in his philosophy," Newman has "gone above and beyond the call of duty in assigning to love the highest place of honor in his epistemology: he has argued that love is the true safeguard of faith, the corrective principle which keeps implicit reason in line." If the reason involved in faith is implicit and dependent on one's loves or affections, how can any particular faith be more rational than any other?

Taking on Jay Newman and other critics of the appeal to the passional nature, William Wainwright has defended its epistemic role. Wainwright follows William James in thinking of our passional nature as including, for example, "our temperament, needs, desires, concerns, fears, hopes." Importantly, Wainwright insists that our passional nature is not necessarily detrimental to the process of assessing religious belief. It may play a legitimate role in shaping our evaluation

\footnotetext{
2 Newman, US, ed.James David Earnest and Gerard Tracey (Oxford: Clarendon Press, 2006), 136.

Newman, US, 134.

Newman, US, 165.

Newman, US, 162.

See, for example, Owen Chadwick, The Mind of the Oxford Movement (Stanford: Stanford University Press, 1960), 42-45; and Anthony Kenny, "Newman and Victorian Doubt," New Blackfriars 92, no. 1038 (2011): 157-69.

7 Jay Newman, "Newman on Love as the Safeguard of Faith," Scottish Journal of Theology 32, no. 2 (1979): 143-44.

8 William J. Wainwright, Reason and the Heart: A Prolegomenon to a Critique of Passional Reason (Ithaca: Cornell University Press, 1995), 5.
} 
of the evidence. Though wishes, desires, and dispositions can certainly get in the way of forming true beliefs, they may have "positive epistemic value." ${ }^{9}$ Wainwright agrees with John Henry Newman that some antecedent assumptions or a properly disposed mind can put one in a place to perceive things correctly. What matters is whether a particular kind of commitment or a properly disposed heart and mind puts one in a better position to have or evaluate evidence and thus increases the likelihood of acquiring true beliefs. Furthermore, Wainwright shows that the insistence that rational belief only stems from skeptic-persuading, consensus-producing arguments (that begin from neutral, public reasons no less) "sets an impossibly high standard" ${ }^{10}$ that John Henry Newman rightly rejects. ${ }^{11}$

Wainwright's response to the problem of adjudication is more plausible than Jay Newman's and the other critics of the appeal to the passional nature. Still, Wainwright's response leaves John Henry Newman and the epistemic legitimacy of our passional nature inadequately defended. Perhaps the more pressing point of Jay Newman and other critics is that John Henry Newman allows non-justifiers like the passions, affections, and emotions to justify faith. Wainwright, for his part, leaves one with the impression that it is legitimate for Newman and other advocates of our passional nature to add our emotions to our current evidence, let our emotions color the objective evidence, or believe something beyond what the evidence warrants. ${ }^{12}$

9 Wainwright, Reason and the Heart, 73. See also Mark Wynn, "The Relationship of Religion and Ethics: A Comparison of Newman and Contemporary Philosophy of Religion," Heythrop Journal 46, no. 4 (Oct. 2005): 438.

10 Wainwright, Reason and the Heart, 75. As William R. Fey points out, the Oriel Noetics' "criterion for reasonable belief," according to Newman, is "artificially narrow. Many do hold a reasonable faith and not merely an ungrounded commitment although they are not able to put their evidence into logical form." In other words, the "degree of evidence is not always proportionate to the degree of formalization." William R. Fey, Faith and Doubt: The Unfolding of Newman's Thought on Certainty (Shepherdstown, WV: Patmos, 1976), 2.

11 In seeking to challenge a narrow conception of reason, Newman employs a parity argument. He highlights the ways in which presumptive reasoning factors into the formation of religious and non-religious beliefs alike. The strength of antecedent probabilities ensures a reliable process of belief-formation in everyday life. So, faith is "not the only exercise of Reason, which, when critically examined, would be called unreasonable, and yet is not so" (US, 147). In fact, much of our belief formation (and the accompanying reasoning) is "tacit and informal. It cannot be neatly displayed as a set of conclusions derived by a straightforward process of inference from clear-cut premisses." Basil Mitchell, Faith and Criticism (New York: Clarendon Press, 1994), 12. There is ample empirical evidence that most people operate on the level of presumptive reasoning until "antecedent probabilities fail" (Newman, US, 135).

12 Wainwright says, for instance, that our emotions and other passional factors "sometimes rightly affect our assessment of a body of evidence" (Wainwright, Reason and the Heart, 58). In other words, these factors are neither evidence themselves nor are they pre-evidential (i.e., things that simply affect what evidence we have in the first place). Similarly, he indicates that our personal character affects our judgments about the evidence and how to 
We freely admit that Newman's position can sound like this at times. But this looks irrational to us, as it surely does to many others. Wainwright helpfully reveals that criticisms of the passional nature consistently assume a restricted and unrealistic conception of reason and thus begs the question against Newman's position. However, showing that the affective aspect of our cognitive pursuits is unavoidable and that criticisms against it are fallacious does not fully defend Newman and the use of our passional nature in the pursuit of epistemic goods. ${ }^{13}$ At most, Wainwright shows that "(under the right conditions) passion, sentiment, and affection may be necessary conditions of using our cognitive faculties correctly." 14

What is needed is a positive reason to think that passional factors are epistemic and therefore can act as justifiers. After all, adding a non-justifier to inadequate evidence still equals inadequate evidence. In what follows, we provide a more adequate defense of Newman's insistence upon the epistemic relevance of our passional nature. To do this, we must be clear about what evidence is and about the nature of passional factors like emotions. Having done so we will be in a position to see how such passional factors can act as legitimate justifiers.

\section{BROADENING THE NOTION OF EVIDENGE}

The standard charge against our passional nature holds that emotions, affections, and passions are not part of our evidence. This charge presumes that evidence is something "out there," rather than something internal or mental, and so evidence is restricted largely to publicly available reasons or even arguments. While Wainwright rightly holds that rationality is perspectival (as Newman says, there is no "common measure between mind and mind"15), Wainwright appears to agree with Newman's critics in holding that evidence consists in publicly available arguments. In this sense, we think Wainwright concedes too much; he concedes a narrow construal of evidence and then seeks to add our passional nature to it. Once we become clear about what evidence is, however, we can see that there is no need to separate evidence and our passional nature in the first place.

\footnotetext{
weigh it (i.e., character affects evidence through volitions rather than simply affecting how we see the world and what evidence we have in the first place). Hence, he often treats passional factors as things that affect the objective evidence itself, even if he recognizes that evidence "is not always fully stateable or universally accessible" (57). Wainwright is not alone in this interpretation of Newman. For example, Basil Mitchell describes Newman's view in a comparable way: "In estimating the force of the evidence and in deciding what is to be believed on the strength of it we are rightly influenced by considerations other than those provided by the evidence itself" (Mitchell, Faith and Criticism, 14).

13 Wainwright is quite aware of this, of course-hence his subtitle: A Prolegomenon to a Critique of Passional Reason.

14 Wainwright, Reason and the Heart, 154. Emphasis added.

15 Newman, GA, ed. Ian T. Ker (Oxford: Clarendon Press, 1985), 60.
} 
At a broad level, there are only a handful of ways to think about epistemic evidence, or evidence for beliefs. ${ }^{16}$ Call the concept handed down to us from the Enlightenment, and with which we are all familiar from legal contexts, "the courtroom conception" of evidence. This view holds that evidence consists in publicly available objects like murder weapons and fingerprints, or at least publicly available reasons and arguments. This is the view that seems to be expressed by both Wainwright and Newman's critics and which leads to the problem of adjudication. If evidence, by its nature, consists in good, neutral, third-person reasons or arguments, then it becomes a serious problem as to why we disagree and how we resolve such disagreements. And when we do disagree-at least when we are both aware of the public reasons and arguments-it would seem that at least one of us must be irrational. ${ }^{17}$

While it might make sense in courtroom contexts to speak of the knife found in the corpse as evidence, notice that evidence for beliefs must consist in the evidence we actually possess. If evidence is just stuff "out there," but no one possesses it or has experience with it, it would hardly seem to justify their beliefs. In addition, this view faces the problem of misleading evidence. We can easily see that if a person possesses good but misleading evidence, they can hold a false but rational belief. For instance, a witness seemed to see Sam at the grocery store at the time of the bank robbery and thus believes that Sam cannot be the robber. However, what she saw was not Sam but Sam's twin of whom she was unaware. The most natural thing to say is that the witness holds a false but rational belief based on good but misleading evidence that Sam was at the grocery store. If seeming to see Sam in broad daylight does not constitute good evidence for Sam's presence, it is difficult to see how our ordinary perceptual beliefs are justified when they are based on such appearances.

Such considerations have led most philosophers to a more internal view of evidence (sometimes called "mentalism"). That is, they have been led to a first-person rather than third-person view of evidence. Evidence here is not "stuff" but rather reasons to believe things or mental states like sensations or appearances that are in some way private to individuals. In our experience, similarly situated individuals tend to see similar things and form similar beliefs, and they will tend to approach most situations with more or less similar background beliefs about

16 Here we follow Logan Paul Gage, "Can Experience Fulfill the Many Roles of Evidence?," Quaestiones Disputatae 8, no. 2 (Spring 2018): 87-111. Because it is not as prominent and we have limited space, we leave off what this article dubs "the Williamsonian view of evidence" inspired by Timothy Williamson. Still, it has some importance in the recent literature.

17 For defenses of the claim that having a better view of evidence can solve this problem, see Nathan L. King, "Disagreement: What's the Problem? or A Good Peer is Hard to Find," Philosophy and Phenomenological Research 85, no. 2 (2012): 249-72; and Logan Paul Gage, "Evidence and What We Make of It," Southwest Philosophy Review 30, no. 2 (2014): 89-99. 
ontology and so forth. Hence, this view does not entail a kind of solipsism or relativism, as it might at first appear.

Among those who hold such internal views of evidence, some have held that our basic or foundational experiences, if we dig all the way down to what is truly "given," consist in sensations-color patches of green, a buzzing sound, and so forth. Classical empiricists like Hume held such a view, as did typical logical positivists who held to a sense data theory. ${ }^{18}$ However, this view seemed to end in skepticism, since we do not have clear sensations of important concepts like "the self." Perhaps most importantly, raw sensations just do not seem to have the right sort of content to justify beliefs. How could certain brown sensations justify a belief in cats more than a belief in Quine's cat parts and so forth?

The other main camp of internalists about evidence consists in those who think that evidence consists in appearances or "seemings." ${ }^{19}$ It is often referred to as "the phenomenal conception" of evidence. On this view, evidence consists in experiences of the way things seem. These are conscious experiences in which the contents are presented as actual. In comparison to daydreaming about seeing a tree, actually seeming to see a tree has this "assertive" character. ${ }^{20}$ This experiential evidence avoids the chief problem facing sensation or sense data theories of evidence, in that seemings have propositional content. Hence, they can plausibly justify beliefs about the content of the seemings. For example, seeming to see a tree can, absent defeaters, justify belief that there really is a tree present-even if one could possibly be mistaken because of exotic factors like Descartes's evil demon or less exotic factors like a hallucination as a side-effect of medication.

The phenomenal conception of evidence has many supporters because of the advantages already mentioned..$^{21}$ Newman obviously does not have such an exact

18 Interestingly, the early logical positivists in the Vienna Circle held to a mentalist conception of evidence but grew uncomfortable with it because of their commitment to materialism and their worries about adjudication if we all literally have different evidence. On this history, see Logan Paul Gage, "Objectivity and Subjectivity in Epistemology: A Defense of the Phenomenal Conception of Evidence," (PhD diss., Baylor University, 2014), ch. 1.

19 This camp consists of both moderate evidentialists like Earl Conee and Trent Dougherty as well as classical foundationalists like St. Augustine or, more recently, Timothy McGrew, who think that our foundational beliefs about our seemings cannot be mistaken. See Earl Conee and Richard Feldman, Evidentialism: Essays in Epistemology (New York: Clarendon, 2004), 15; Trent Dougherty, "Further Epistemological Considerations Concerning Skeptical Theism," Faith and Philosophy 28, no. 3 (July 2011): 332-40; and Timothy McGrew, "A Defense of Classical Foundationalism," in Louis P. Pojman, ed., The Theory of Knowledge: Classical and Contemporary Readings, 3rd ed. (Belmont, CA: Wadsworth/Cengage Learning, 2003), 194-206.

20 For more on the nature of seemings, see Logan Paul Gage and Blake McAllister, "Phenomenal Conservatism," in Debating Christian Religious Epistemology: An Introduction to Five Views on the Knowledge of God, eds. John M. DePoe and Tyler Dalton McNabb (New York: Bloomsbury Academic, 2020), 66.

21 An additional advantage is that a plausible notion of epistemic justification emerges 
conception of evidence, but we think that this internal sense of evidence-with its shift from a third-person understanding of evidence to a first-person perspective-fits with and elucidates his epistemology. For instance, one consistent theme of Newman's epistemology is that there are two different senses of evidence: evidence as public arguments that anyone could accept and evidence in the sense of first-person reasons (which are often implicit rather than explicit). Newman makes a distinction between the evidential considerations of faith and the articulation of them in a publicly accessible manner. ${ }^{22}$ In addition, he construes evidence in personal terms. As he says,

the Evidences are for public disputations and lectures in the Schools; but the faith and reason, of which I speak, are subjective, private, personal, and unscientific; the mental acts of every Christian whatever, except when they are merely hereditary and mechanical, and therefore unworthy of the name ... This then is the thesis which I shall make the occasion of an Essay upon the nature of the personal evidence on which the mass of Christians individually believe. ${ }^{23}$

Newman's lifelong insistence was that there are reasons for faith but that such reasons need not consist in publicly available evidence or arguments. "Faith must rest on reason," Newman writes, "nay even in the case of children and of the most ignorant and dull peasant." ${ }^{24}$ This is a clear differentiation, it seems, between the external or courtroom conception of evidence mentioned previously and a more internal view of evidence like the phenomenal conception. It indicates not only that there is evidence for faith but that this evidence is internal and personal rather than merely external and public. Children, after all, are unaware of sophisticated Christian apologetics.

naturally from this view of evidence. Absent defeating evidence, one has some degree of justification for believing that which appears true on balance. And the strength of one's justification is proportional to the strength of the seeming. This understanding of justification, known as "phenomenal conservatism," has a number of able defenders and fits nicely with the phenomenal conception of evidence. See especially Michael Huemer, Skepticism and the Veil of Perception, in Studies in Epistemology and Cognitive Theory (Lanham, MD: Rowman \& Littlefield, 2001); Seemings and Justification: New Essays on Dogmatism and Phenomenal Conservatism, ed. Chris Tucker (New York: Oxford University Press, 2013). It offers a moderate form of evidentialism in that beliefs must be based on evidence, but evidence can be misleading and consists not in publicly available arguments but in first-person experiences.

22 Newman, TP, ed. Hugo M. de Achaval and Derek Holmes (Oxford: Clarendon Press, 1976), 121; and Geertjan Zuijdwegt, "Richard Whately's Influence on John Henry Newman's Oxford University Sermons on Faith and Reason (1839-1840)," Newman Studies Journal 10, no. 1 (Spring 2013), 82-95.

23 Newman, TP, 84-86. Emphasis added; see also US, 178; GA, 249; Newman, "Faith without Demonstration," PS (San Francisco: Ignatius Press, 1987), vi. 1384-86.

24 Newman, TP, 29. 
So, faith, for Newman, is not groundless. It is "independent not of objects or grounds (for that is impossible) but of perceptible, recognized, producible objects and grounds." As a result, faith "admits, but does not require, the exercise" of explicit reasoning. ${ }^{25}$ In other words, the reasoning of faith includes but is not reducible to explicit reasoning. Even though Newman thinks that faith has grounds (or rests on evidence), "some of it cannot be easily recovered or stated, and the evidence as a whole is likely to seem weak to those with some moral temperaments. ${ }^{26}$ In perfectly ordinary cases, our evidence is too subtle and complex to easily articulate. ${ }^{27}$ This is why he maintains that "we require an organon more delicate, versatile, and elastic than verbal argumentation." 28 Newman, then, makes a distinction between (a) having grounds for belief and (b) articulating those grounds to oneself or to others. In other words, the operation of the mind ("real" grounds) is not reducible to the capacity to formalize one's reasoning. ${ }^{29}$

With such a broad understanding of evidence, it is easy to see why Newman views emotions and rightly ordered dispositions as crucial to the evidential dimension of faith. This is what Newman seemed to have in mind when he employs the language of an "educated conscience," "cultivated moral perception," "spiritual discernment," "rightly directed reason," and "religiously trained reason." ${ }^{30}$ In other words, Newman was deeply interested in the formative practices, processes, and habits that enable people to develop their cognitive capacities, to be volitionally open to or prepared for the divine, and enlarge their intellectual horizons. ${ }^{31}$ Such an emphasis coheres with Newman's claim that it is the whole person that reasons. As he says, "It is the concrete being that reasons"; "the whole man moves." 32 This is why the whole person needs educating if one is to find the truth-especially in religious matters.

Newman's sensitivity to the actual complexities of our belief-forming processes makes him keenly aware of the fact that we do not merely reason upon public

\footnotetext{
25 Newman, US, 175.

26 Wainwright, Reason and the Heart, 81. On Newman and the grounds of faith, see Frederick D. Aquino, "Newman on the Grounds of Faith," Quaestiones Disputatae 8, no. 2 (2018): 5-18. Newman also thinks it is important to assess the implicit process of reasoning. Assumed here is the recognition that not all grounds are necessarily adequate or truth-conducive. For a contemporary account of adequate grounds, see William P. Alston, Beyond "Justification": Dimensions of Epistemic Evaluation (Ithaca, NY: Cornell University Press, 2005), esp. ch. 5.

27 See Newman, GA, 184, 189, and 213.

28 Newman, GA, 176, see also 208.

29 Newman, US, 149.

30 Newman, US, 49, 51, 56, 58.

31 See Newman, Idea, ed. Ian T. Kerr (Oxford: Clarendon Press, 1976), 97, 111, 120; $L D, \mathrm{xv}, 280$.

32 Newman, Apo, ed. Martin Svaglic (Oxford: Clarendon, 1967), 155.
} 
evidence, nor do we often formulate explicit syllogisms. Instead, the mind works by drawing connections, quickly and implicitly weighing evidence, judging the plausibility of testimony, and so on.$^{33}$ In fact, contrary to the Enlightenment view of reason and evidence, most of our reasoning is implicit rather than explicit; its grounds are not typically publicly available and are only presented to others in syllogistic form with much difficulty. We only engage in this explicit process of reasoning, Newman recognizes, when we examine our reasons at meta-level and think about whether they would be the kind of reasons that others might accept. ${ }^{34}$ The implicit reasoning of faith is not some special process in which only believers engage, but the very process by which we form most of our beliefs. ${ }^{35}$

A further aspect of Newman's position on reasons and evidence that harmonizes nicely with an internal conception of evidence is that antecedent beliefs and assumptions affect what it is rational to believe. If the Enlightenment view is correct, and our only evidence is publicly available evidence, then it would seem illegitimate to let antecedent assumptions and beliefs color our view of the evidence. However, Newman repeatedly claims that such prior mental states rightly affect our judgments. ${ }^{36}$ As Joe Milburn writes, Newman rejects "the idea that all good reasoning is done on the basis of direct evidence, or on the basis of grounds that may be produced by the reasoner. Sometimes good reasoning occurs on the basis of grounds we cannot produce, and it can include more than direct evidence for a belief, namely, antecedent probabilities." ${ }^{37}$ Newman's position seems to indicate that our prior mental states do not just color the evidence, but are part of our total evidence.

For all these reasons, we argue that an internal conception of evidence (such as the phenomenal conception) is not only plausible but fits with and even elucidates Newman's epistemology. ${ }^{38}$ A potential difficulty for this position, however, is that Newman sometimes uses the term "evidence" to designate publicly available reasons and arguments. For instance, he says that faith is "content with weaker

33 See Newman, US, 176-77; GA, 187. Fey argues that in the GA Newman changes the focus a bit. He turns to "the logic of informal reasoning from evidence. Whereas before he had spoken of dispositions converging into a context within which one found evidence forceful or not, now he would speak of evidence converging into a certain, although informal, proof" (Fey, Faith and Doubt, 55).

$34 \quad$ Newman, US, 177.

35 Cf. Newman, US, 151.

36 See Newman, US, 157-58.

37 Joe Milburn, "Faith and Reason in the Oxford University Sermons: John Henry Newman and the Legacy of English Deism," American Catholic Philosophical Quarterly 92, no. 3 (2018): 495.

38 For a more extended look at Newman on evidence, see Frederick D. Aquino, "Towards a Broader Construal of Evidence: A Constructive Look at John Henry Newman," American Catholic Philosophical Quarterly 94, no. 1 (2020): 125-39. 
evidence." ${ }^{39}$ Nothing, for example, ought to be received or believed "without good evidence that it is so: that without some argument sufficient to satisfy a prudent and considerate" person. ${ }^{40}$

Yet, because Newman does not agree with the Enlightenment critics of faith, that is, because he thinks that we legitimately bring in these supposedly extra-evidential factors in our reasonings, we can infer that Newman does not in fact hold to this view of evidence. He rejects the claim that a belief is rational if and only if it can be publicly defended via arguments with uncontroversial premises. He is merely trying not to confuse his readers and hence uses the term "evidence" in the way that has come down to us from the Enlightenment. He clearly does this with the similar term "reason." Newman differentiates reason in the overly narrow sense of having explicit reasons and "expertness in logical argument" from reason in the broader sense of having reasons. ${ }^{41}$ At times this has led to confusion, and Newman being accused of fideism, since he speaks of faith as lacking grounds or going beyond reason—or resting on weak reasons. However, in the total context of his written corpus, it is clear that he is speaking of explicit or even secular reason or worldly wisdom. For instance, he speaks of faith as "an act of Reason, but of what the world would call weak, bad, or insufficient Reason." ${ }^{42}$

Similarly, Newman's observation that one's beliefs can go far beyond the evidence is best read as saying that one's beliefs can go far beyond the restrictive view of evidence as public reasons or arguments. As he writes, "when we come to what is called Evidence, or, in popular language, exercises of Reason" we must exclude all but that which will be publicly admitted into discussion. ${ }^{43}$ "Nothing can be urged ... but what all feel, all comprehend, all can put into words ... the multiform and intricate assemblage of considerations, which really lead to judgment and action, must be attenuated or mutilated into a major and minor premiss." ${ }^{44}$ In other words, Newman recognizes the distinction between our total evidence and that which we sometimes call "evidence," namely, the explicit public reasons one can offer to others. It is no objection to our argument, then, that Newman sometimes uses "evidence" in a very narrow way. The concept of evidence is almost synonymous with having good reasons. ${ }^{45}$ So, when Newman draws the distinction between having reasons and arguing ${ }^{46}$ he recognizes the

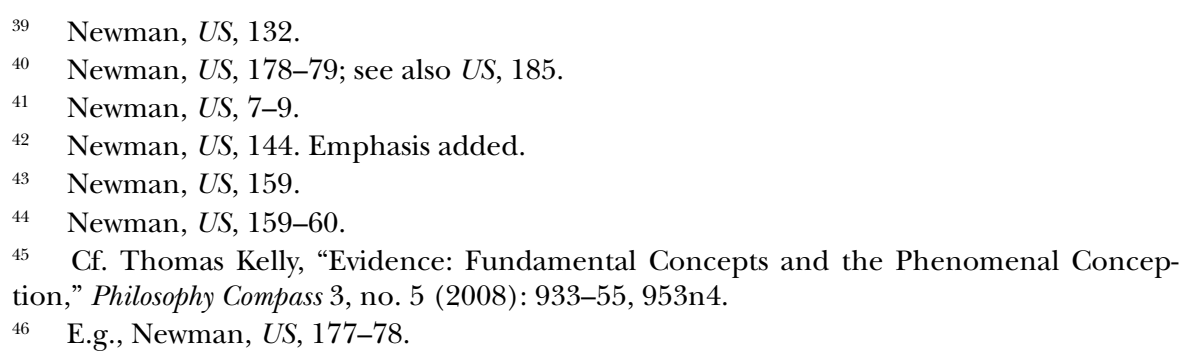


distinction between first-person evidence and third-person, publicly available evidence-between how the mind actually works and how we try to represent such activity in and through logical analysis. The thrust of his thought suggests that a proper view of evidence/reasons is much broader than this narrow conception; and that is all we need for our argument to proceed.

\section{THE GOGNITIVE ASPEGT OF THE PASSIONAL NATURE}

In Newman's time, passions, emotions, and affections were predominantly viewed as non-cognitive states, mere sentiments, or irrational intrusions. So, they would not have been expected to play any role in justifying faith. However, the topic of emotions has become the focus of much contemporary philosophical theorizing. In fact, there has been a growing interest in thinking critically and constructively about the emotions. The emerging consensus is that they are plausibly cognitive. ${ }^{47}$ That is, they are "intelligent, cultivated, conceptually rich engagements with the world, not mere reactions and instincts." ${ }^{48}$ Accordingly, it has been argued that emotions are evaluative judgments, ${ }^{49}$ evaluative perceptions, ${ }^{50}$ or evaluative feelings. ${ }^{51}$ What these various proposals share in common is the claim that emotions are cognitive, intentional, and thus play an important epistemic role in acquiring evaluative knowledge of the world. As representations, they have "a mind-to-world direction of fit." 52

Newman could hardly have anticipated this cognitive turn in the philosophy of emotions. However, Newman's emphasis on the epistemic role of the passional nature fits well with the current trend toward the cognitive view of emotions. In his

47 This is not to say that there is complete unanimity. For a critical look at perceptual models of emotion, for instance, see Michael. S. Brady, Emotional Insight: The Epistemic Role of Emotional Experience (New York: Oxford University Press, 2013). Note further, however, that a parallel revival of the cognitive view of emotions has occurred in the continental tradition via Edmund Husserl (see the fifth of his Logical Investigations where he treats emotions as intentional) and was carried on by Max Scheler, Dietrich von Hildebrand, and others. This signals that the growing consensus on the cognitive nature of emotions is not simply a passing fad of recent analytic philosophy.

48 Robert C. Solomon, The Passions: Emotions and the Meaning of Life (Indianapolis, IN: Hackett, 1993), ix.

49 Martha C. Nussbaum, Upheavals of Thoughts: The Intelligence of Emotions (Cambridge: Cambridge University Press, 2001); Solomon, The Passions.

50 Robert C. Roberts, Emotions: An Essay in Aid of Moral Psychology (Cambridge: Cambridge University Press, 2003); Ronald de Sousa, Emotional Truth (Oxford: Oxford University Press, 2011).

51 Peter Goldie, "Emotion, Feeling, and Knowledge of the World," in Robert C. Solomon, ed., Thinking About Feeling: Contemporary Philosophers on Emotions (Oxford: Oxford University Press, 2004), 91-106; and Peter Goldie, The Emotions: A Philosophical Exploration (Oxford: Clarendon Press, 2000).

52 De Sousa, Emotional Truth, 28. 
sermon on love as a safeguard of faith, for example, Newman clearly thinks that faith is an "intellectual act, done in a certain moral disposition." It involves an implicit kind of "reasoning upon presumptions." ${ }^{53}$ Properly formed faith involves "reasoning upon holy, devout, and enlightened presumptions," namely, "deliberately, seriously, soberly, piously, and humbly, counting the cost and delighting in the sacrifice." ${ }^{54}$

Newman does not offer a comprehensive or systematic account of the passional nature. However, his understanding of the role that the passional nature plays in the evidential considerations of faith is complex and multifaceted. Newman seems to hold the following position. On the one hand, he rejects the claim that faith is "but a feeling, an emotion, an affection, an appetency," and, as a result, the connection of "faith with Truth and Knowledge more and more either forgotten or denied." ${ }^{55}$ In fact, he thinks that the depiction of religion as a "mere sentiment" is "a dream and a mockery." ${ }^{56}$ On this view, which Newman rejects, faith is not based on "argument, but on taste and sentiment." It consists in "something short of intellectual exercises, viz., in the affections, in the imagination, in inward persuasions and consolations, in pleasurable sensations, sudden changes, and sublime fancies. ${ }^{~}{ }_{77}$ Newman rejects this view because it fails to recognize the intellectual aspect of faith and therefore misunderstands the role of the passional nature. ${ }^{58}$

As Newman says, "True philosophy deals with facts. We cannot make facts. All our wishing cannot change them. We must use them." ${ }^{59}$ Newman clearly thinks that wishful thinking is epistemically problematic. It must be constrained by the object or the facts. Our background beliefs, biases, personal inclinations, and so on can get in the way of deciphering correctly (or reliably forming) true beliefs. Both the moral and intellectual aspects of our existence "require and admit of discipline; and, as it is no disproof of the authority of conscience that false consciences abound, neither does it destroy the importance and the uses of certitude, because even educated minds, who are earnest in their inquiries after the truth, in many cases remain under the power of prejudice or delusion." ${ }^{60}$ Our perspective must be expanded, deepened, and completed "by means of education, social intercourse, experience, and literature." ${ }^{61}$

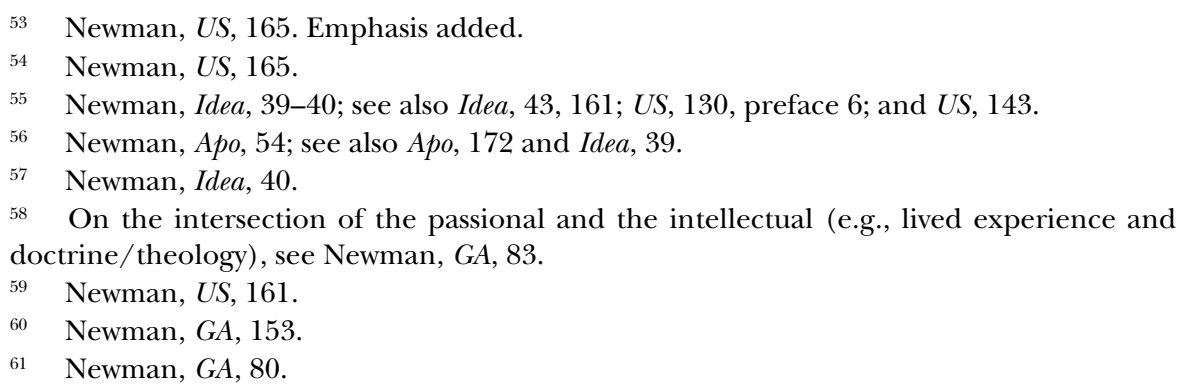


On the other hand, Newman thinks that the passional nature can be epistemically beneficial. A properly disposed mind can put one in a place to perceive things correctly or even to perceive something that otherwise would not be perceived at all. ${ }^{62}$ What matters is whether a particular kind of commitment, or a properly disposed mind, puts one in a better epistemic position. Along these lines, Newman also makes a connection between love and the acquisition of particular epistemic goods. In fact, he thinks that reason and the passional nature are both instruments for acquiring knowledge of God. ${ }^{63}$ What Newman insists on is the importance of a properly formed mind or the possession of an abiding disposition. "The divinely-enlightened mind sees in Christ the very Object whom it desires to love and worship,- - the Object correlative of its own affections; and it trusts Him, or believes, from loving Him." ${ }^{64}$ In this respect, love, far from distorting our outlook, is an abiding disposition for knowledge of God. "To say that 'love is the parent of faith' is true, if by 'love' is meant . . . that desire for the knowledge and drawing towards the service of our Maker." Moreover, this abiding disposition does not "stand in antagonism or in contrast to Reason, but is a sovereign condition without which Reason cannot be brought to bear upon the great work in hand." ${ }^{65}$

Faith, as "an intellectual act" takes "its character from the moral state of the agent" and is thus "perfected" by obedience. It is "the presumption of a serious, sober, thoughtful, pure, affectionate, and devout mind." ${ }_{66}$ Love, for example, is "the eye of Faith, the discriminating principle which keeps it from fastening on unworthy objects, and degenerating into enthusiasm or superstition." ${ }^{7}$ The distinction here, then, seems to be between an improperly and properly formed heart and mind. Contrary to what Chadwick and others suggest, Newman does

62 In Belief (London: George Allen \& Unwin, 1969), 471f. H. H. Price makes a comparable point: "The latent assumption which needs to be made explicit is this: that a person's character, the conative and emotional dispositions he has acquired, affects his cognitive powers and enables him to be aware of the facts he could not otherwise be aware of .... The assumption is that a person who has acquired conative and emotional dispositions is able to have experiences disclosing facts to him which others are not able to discern." Newman seems to be saying something similar. Our passional nature, when properly ordered and cultivated, puts us in a better position to decipher or sense the voice of the divine, though we are still subject to potential distortions or misunderstandings.

63 On reason, see Newman, US, 60. Fey says that Newman's "emphasis on personal dispositions was not meant to displace evidence" but to highlight "the personal nature of reasoning toward faith" (Fey, Faith and Doubt, 22).

64 Newman, US, 164.

65 Newman, DA, $3^{\text {rd }}$ ed. (London: Pickering and Co., 1878), 251.

66 Newman, US, 172. Emphasis added.

67 Newman, US, 165 and 166. When discussing 1 John 2:27, for example, Newman says the faculty "by which we know the Truth is here represented to us, not as a power of investigation, but as a moral perception" (US, 165). 
not divorce reason from love as a safeguard of faith but rather seems to suggest that love properly construes and responds to the object of faith. Love is a vital part of our cognitive apparatus whereby we come to perceive things divine, thereby ruling out inappropriate depictions of the divine.

What Newman is after is a well-formed affective or passional nature that is more likely to attain the truth. With this in mind, Mark Wynn argues that Newman's account suggests that "affections may themselves be intellectual; accordingly, on this view, we could suppose that the perception of the beauty and loveliness of the Lord is itself affectively toned, so that it is not a matter of the affective state (of loving or hating) following on from the understanding or vice versa; rather, the understanding of the Lord's loveliness is realized in the affection." ${ }^{68}$ Wynn rightly shows that "before our reason is deployed, we need to decide what to think about; and the emotions have a role in this regard, by picking out matters which are worthy of attention. And since we need some such initial orientation if our enquiries are to get started, their role in this respect is at least prima facie innocent." ${ }^{69}$ An initial orientation includes and is shaped by antecedent considerations, practices, and experiences. ${ }^{70}$ Employment of the passional nature is not merely an appeal to an inner state or feeling. Rather, it has an object as its focus; yet, it must attend rightly to such an object. In this sense, the passional nature has a truth-detecting function.

So, Newman thinks that an evaluative perception of this sort complements the deliverances of reason. The passional nature, then, is not necessarily set in opposition to reason. In fact, its deliverances can be analyzed by reason as appropriate or inappropriate construals of reality. Yet, they do not rely on the formal insights of reason before they construe the proper object of faith. When faith works by love, "the honest mind may, under ordinary circumstances, be led, and practically is led, into an acceptable, enlightened, and saving apprehension of Divine Truth without that formal intimacy and satisfaction with the special evidence

\footnotetext{
68 Wynn, "The Relationship of Religion and Ethics," 445.

69 Wynn, "The Relationship of Religion and Ethics," 439. On the role that emotions play in training our attention and attuning us to the world around us, see Mark R. Wynn, Emotional Experience and Religious Understanding: Integrating Perception, Conception and Feeling (Cambridge: Cambridge University Press, 2005); and Robert C. Roberts, Emotions: An Essay in Aid of Moral Psychology (Cambridge: Cambridge University Press, 2003).

70 As Fey points out, Newman "was careful to emphasize that the complex intellectual activity by which we come to know, is often or always surrounded by personal factors, moral dispositions and antecedent assumptions" (Faith and Doubt, 153). However, the "role of moral dispositions and will is not to replace reasons or to make us act on insufficient evidence, but to aid the mind in recognizing a speculative or a practical truth in a complex of evidence." A properly regulated or educated conscience, for Newman, creates the right kind of orientation by which we have a rightly ordered passional nature (see, for example, Newman, US, $48-61$, and $G A, 75)$.
} 
existing for the facts believed, which is commonly called Reasoning, or the use of Reason, and which results in knowledge." ${ }^{\prime 1}$ Reason may critically evaluate the "grounds and motives" of a moral act, but it does not function as the motive of the act itself. ${ }^{72}$ An explicit mode of reasoning, may analyze the grounds of faith, but it is not typically the source from which faith arises. In essence, Newman rejects the claims that (a) reason is that which produces faith (hard rationalism) and (b) faith ought to be exempt from rational analysis (fideism). In sum, Newman's claim that it is the affective side of the person and, in particular, love, that properly forms the mind and predisposes the intellect toward the truth fits well with the emerging philosophical consensus concerning a cognitive role for the emotions.

\section{DEFENDING NEWMAN AND THE PASSIONAL NATURE}

With this growing trend in the emotions literature in mind, we are now in a position to see how at least some emotions and perhaps related states can, as Newman intimates, serve as appropriate justifiers of belief. On the emerging consensus, emotions have the right sort of content to justify beliefs. ${ }^{73}$ On the view of emotions as raw feelings, it would be impossible for emotions to justify any particular belief because they lack propositional content. ${ }^{74}$ If a subject $S$ 's anger is just a feeling - a burning sensation, for instance - then it is hard to see what sort of beliefs it could justify for $\mathrm{S}$. That is, it is difficult to see how a sensation can bear a relation of rational support to a belief, let alone to one particular belief rather than another. ${ }^{75}$ If, however, S's anger functions more like a perception-if, say, Sally's anger is a construal of a situation as unjust-then Sally's anger can plausibly (even if defeasibly) justify the belief that an injustice has been committed in the same way that the perception of a tree defeasibly justifies belief in the presence of a tree.

Nonetheless, even if emotions like fear or anger have the right sort of content to justify relevant beliefs, they cannot do so on the third-person, public view of evidence. Sally's anger would not seem to justify the presence of a perceived injustice so long as evidence is understood as public evidence or objects. After

\footnotetext{
71 Newman, US, 166. Emphasis added.

72 Newman, US, 131.

73 This is not to say that all advocates of the cognitive view of emotions take emotions to justify.

74 One reason to think that not all emotions and related states can justify beliefs is that not all such states appear to have intentional objects or propositional content. Hence, some have argued for a distinction between emotions in this rich sense and mere moods. See Roger Lamb, "Objectless Emotions," Philosophy and Phenomenological Research 48, no. 1 (Sept. 1987): 107-17.

75 We take it that in every case of epistemic evidence where $\mathrm{E}$ supports $\mathrm{B}(p)$, there is some evidence $\mathrm{E}$, some belief with content $p$, and a relation of support from $\mathrm{E}$ to $p$. Without relevant propositional content, $\mathrm{E}$ seems unable to bear this relation to $p$.
} 
all, the experience of anger is not a publicly available object or argument; on the courtroom conception of evidence, therefore, it is not evidence at all. However, if the phenomenal conception is correct, as we have argued, and epistemic evidence is best understood as seemings or first-person experiences with propositional content, then we can see how emotions and similar states can rightly justify belief. Sally sees a mugging in an alley and immediately becomes angry; she perceives the very injustice with both her mind and body. It seems to her that injustice has been committed; she both feels it and is cognitively aware of it (even if not in these exact terms). It is a good thing for us to be built this way. Having emotions that quickly justify beliefs without making explicit inferences helps us more quickly and naturally respond to danger and injustice.

It is easy to see how many would view beliefs made on the basis of emotional construals of the world as non-cognitive or mere instinct, since the logical connections are defeasible rather than indefeasible and are often made by the subject quickly rather than slowly, passively rather than deliberately, and implicitly (i.e., non-inferentially) rather than explicitly. However, as Newman rightly indicates, this sort of grounding in reasons-even if not in reasons of which we are fully and explicitly aware, as in a formal deductive argument-is not only rational but our dominant modus operandi as human beings. We see the lights on in the office next to us and assume that our colleague is in; we notice that our spouse's car is not in the driveway and behave as if our spouse is not home; or we see terrified people running in one direction and quickly join them. All these things happen without much, if any, conscious reasoning. In most cases, if we were pressed, we could identify the support relations that we have tacitly perceived and make them explicit, but perhaps not always. ${ }^{76}$ If making these connections explicit were a condition of rationality, then we are all fundamentally irrational-and thus there is no special problem about emotions. Hence, Newman advises that we pay attention to how our cognitive capacities actually operate rather than theorize about them in the abstract. The appeal here is to the natural "constitution of the mind as we find it," not to how we think it ought to work. ${ }^{77}$

At any rate, it seems clear that emotions often indicate states of affairs to us (e.g., that a dangerous object is present, that injustice is being committed, or that this person is lovely and valuable) and that we have the ability to perceive evidential support relations without making our reasons explicit. If this is right, and if the first-person understanding of evidence is correct, then emotions appear to have the

76 For more on perceiving evidential support relations tacitly, see Blake McAllister and Trent Dougherty, "Reforming Reformed Epistemology: A New Take on the Sensus Divinitatis," Religious Studies 55, no. 4 (Dec. 2019): 537-57.

77 Newman, GA, 142. 
ability to justify beliefs, at least under appropriate conditions. ${ }^{78}$ We can make sense of why normal human beings take emotions and related states as evidence instead of meeting the Enlightenment ideal: it is because this is a fully rational thing to do ${ }^{79}$

Combining these contemporary insights about the nature of evidence and emotions, we are now in a position to see a more adequate reply to the standard charge against Newman than that offered by Wainwright. Wainwright makes it sound as if Newman's recognition of the legitimate role of emotions privileged the non-cognitive in epistemic matters. However, with a cognitive view of emotions, we can see Newman as rightly insisting that cognitive emotional experiences and proper affective dispositions do not so much add to our evidence as give us evidence in the form of construals of the world. On the phenomenal conception of evidence, emotions and affective dispositions affect which evidence we hold in the first place rather than color or skew our evidence. Importantly, they do not add to our evidence or distort it because these factors act pre-volitionally (before judgments) and pre-evidentially (i.e., since they affect what evidence we have or how we see the world and thus affect what we passively receive, they do not stand in need of justification themselves). That is not to say, however, that honing our affections and our perceptual sensitivities and abilities is not something we should do or are responsible for diachronically. Over time, we can retrain our emotional responses so as to construe reality better.

This understanding of evidence and emotions enables us to move beyond Wainwright's negative rebuttal of Newman's critics and provides positive reason for thinking that emotions, which seemed initially like illegitimate non-justifiers, can play a legitimate epistemic role: they have the right content and are not added to our evidence but affect what evidence we have in the first place, for good or ill. Recognizing that our character and training affects what evidence we have makes sense of why emotions, affections, and passions often help us toward the truth rather than only lead us astray (as one might expect on a non-cognitive view of emotions) ${ }^{80}$

78 For recent sustained defenses of this claim, see Linda Trinkaus Zagzebski, Epistemic Authority: A Theory of Trust, Authority, and Autonomy in Belief (New York: Oxford University Press, 2012): 75-98; Robert C. Roberts, Emotions in the Moral Life (New York: Cambridge University Press, 2013): 38-67; and Adam C. Pelser, "Emotion, Evaluative Perception, and Epistemic Justification," in Emotion and Value, eds. Sabine Roeser and Cain Todd (Oxford: Oxford University Press, 2014): 107-23.

79 For evidence that we do take emotional experiences as evidence and adjust our beliefs accordingly, see Gerald L. Clore and Karen Gasper, "Feeling Is Believing: Some Affective Influences on Belief," in Emotions and Beliefs: How Feelings Influence Thoughts, ed. Nico H. Frijda, Antony S. R. Manstead, and Sacha Bem (Cambridge: Cambridge University Press, 2000): 10-44.

80 Newman emphasizes that a special habit or preparation of mind is required in different areas of inquiry. See $G A, 266$ and $L D$, xxiv, 119. 
Moreover, while some have thought of the appeal to our passional nature as special pleading for religion, ${ }^{81}$ in truth, this application of the nature of emotions and evidence is perfectly general. In ordinary family matters, for instance, one will not get at the truth without a right heart. If children are seen only through the lens of selfish concerns, for instance, one's heart hardens as children are construed as an annoyance rather than a blessing. That is, without love, we misconstrue the reality of their value. Hence, when Newman argues that love is the safeguard of faith, he need not insist on some special role for emotions and affective dispositions not in play in more mundane affairs. Hence, we conclude not only that Newman need not be guilty of letting non-justifiers justify religious beliefs, but that he plausibly offers a quite general epistemology applicable outside the bounds of religious discourse-one that appears to have stood the test of time. With a proper view of evidence and emotions we can see that Newman was right: faith can be partially rooted in emotions and affective dispositions and still be an intellectual, rationally-grounded act. Our whole person, including our affections and habits of mind, comes into play in both religious and non-religious cases. ${ }^{82}$

\section{GONGLUSION}

We have argued that contemporary ideas about evidence and emotions help us see how Newman's position on the epistemic role of our passional nature is not only coherent but humane and winsome. The conclusion that emotions and related passional factors may at times play a legitimate epistemic role is important and substantive in its own right. But we think that there is a further lesson. We hope to have shown how fruitful it is to put Newman's core ideas into dialogue with the best of contemporary philosophy. Contemporary analytic philosophy, in particular, has been criticized for its in-depth, seemingly pedantic analysis of language and concepts. However, such in-depth analyses can be incredibly fruitful when made to fill out broader but under-developed claims-just the sort of claims we sometimes find in the corpus of Newman's writings. In light of this careful work on evidence and emotions we can better appreciate Newman's insistence upon an epistemic role for our passional nature. ${ }^{83}$

\footnotetext{
81 Cf. Wainwright, Reason and the Heart, 83.

82 We do not deny that there is also a supernatural cause of faith. We only mean to assert that the case of faith is not as different from ordinary cases as it might first appear with regard to evidence and emotions.

${ }_{83}$ We wish to thank John Crosby and Ryan West for helpful comments on a previous draft of this essay.
} 